\title{
Measuring fiscal descentralization in Argentina and Denmark
}

\author{
Midiendo la Descentralización fiscal en Argentina y Dinamarca
}

Cristian Altavilla*

Universidad Siglo 21

Córdoba, Argentina

\begin{abstract}
Fiscal decentralization has been a worldwide trend in the last decades, especially in Europe and in Latin America. This process, however, have not been uniform in all countries, acquiring different forms in different countries and within a same country over the years; those processes even involved not only federal states, but also traditionally unitary states. Decentralization, then, is a concept that has broken the theoretical boundaries between unitary states and federal states, transcending them. Therefore, a comparative study not only between federal countries but also between unitary countries is required. The aim of this paper is to compare the process of decentralization in two countries with completely different institutional settings (Argentina and Denmark) in order to measure the degree of fiscal decentralization reached, to understand how this process has operated throughout the last decade and which outcomes has been achieved in these two countries.
\end{abstract}

KEY WORDS: decentralization; fiscal federalism; subnational governments; local autonomy; taxation.

RESUMEN: La descentralización fiscal ha sido una tendencia mundial en las últimas décadas, especialmente en Europa y América Latina. Este proceso, sin embargo, no ha sido uniforme en todos los países, adquiriendo diferentes formas en distintos países y dentro de un mismo país a lo largo de los años; estos procesos incluso involucraron no solo Estados federales, sino también Estados tradicionalmente unitarios. La descentralización, entonces, es un concepto que ha roto las fronteras teóricas entre los Estados unitarios y federales, trascendiéndolas. En consecuencia, un estudio comparativo no solo entre Estados federales sino también entre Estado unitarios resulta necesario. El objetivo de este trabajo es comparar el proceso de descentralización en dos países con diseños institucionales completamente diferentes (Argentina y Dinamarca) con la finalidad de medid el grado de descentralización fiscal alcanzado, para entender cómo han operado estos procesos a través de la última década y qué resultados se han alcanzado en estos dos países.

PALABRAS CLAVE: descentralización; federalismo fiscal; gobiernos subnacionales; autonomía local; tributación.

\section{INTRODUCTION}

\footnotetext{
${ }^{*}$ Ph.D. in Law and Social Sciences (University of Córdoba, Argentina) with a Ph.D. Visiting in Political Science at Bologna University Italy. Assistant Professor of Subnational Constitutional Law, School of Law, National University of Córdoba and Siglo 21 University (UES21), Córdoba, Argentina. Director of the School of Law UES21 University, Postdoctoral Researcher (CONICET, Argentina) and Postdoctoral Fellow at Aarhus University, Denmark and Harvard University. e-mail: cristianaltavilla@ hotmail.com
} 
Decentralization of functions and competences from central governments to subnational units (intermediate and/or local levels) has been a worldwide trend in the last decades. This process, however, have not been uniform in all countries, acquiring different forms in different countries and within a same country over the years. The most significant thing it was the fact that decentralization has occurred in different institutional settings, involving not only federal states, but also traditionally unitary states.

A comparative study not only between federal countries but also between unitary countries is required. The underlying concept of decentralization appears. The different processes of decentralization (political, administrative, fiscal, spatial, etc.) all around the world, involving even traditionally unitary countries, makes it difficult to distinguish between those decentralized-unitary countries from federal countries. Decentralization, then, is a concept that has broken the theoretical boundaries between unitary states and federal states, transcending them. And the question of how different are federal and unitary constitutional arrangements in practice arises: "Even in unitary states central governments are rarely as autonomous as the formal institutional set-up might indicate. They depend on the resources of actors in their surroundings for political support, information, expertise or implementation of policies. Formal institutions are underpinned or supplanted by informal policy networks in which central government actors interact with actors in their surroundings in order to formulate and implement policies"1. In federal countries, in turn, may occur the opposite: In fact, it may be that subnational units in federal systems more often underutilize their constitution-making competency than they overutilize it.

Being aware that decentralization not necessarily raises the power of subnational governments in all cases, as commonly thought ${ }^{2}$, and beyond normative considerations regarding fiscal decentralization ${ }^{3}$, this paper is focused on the question regarding the degree in which fiscal decentralization has occurred in countries with different institutional settings. This rises the following research questions: ¿in which extent or degree fiscal decentralization has occurred? ¿how fiscal decentralization has operated and which outcomes has achieved in different institutional settings? ¿in which extent the different process of fiscal decentralization increased the degree of fiscal autonomy of subnational governments?

With these questions in mind, the paper intends to compare two different countries: Argentina and Denmark. Subnational units in Argentina and Denmark operate within different political, economic and legal frameworks. Denmark, like the rest of the Scandinavian countries, has decentralized to such a degree that many scholars lumped it together with the federal states, because their local governments absorb such high shares of total public expenditure (Ter-Minassian 1997; Fossati and Panella 1999; Wellisch 2000 - quoted by Swenden ${ }^{4}$ ). The comparison between these two cases will help us to understand the similarities and differences between unitary and federal arrangements. I have chosen the period 2000-2010 in order to test the current stage of decentralization in the new millennium and because there is a significant gap in the current literature regarding the last decade.

\footnotetext{
${ }^{1}$ BLOM-HANSEN (1999) p. 238.

${ }^{2}$ See FAlleti (2005).

${ }^{3}$ See Tiebout (1956), OAtes (1972) and Ter-Minassian (1997).

${ }^{4}$ SWENDEN (2006) p. 17.
} 
Considering the legal framework, federal countries should be more decentralized than unitary ones. However, as RODDEN has noted, empirical studies take issue with this statement $^{5}$. While on the one hand, Argentina has a federal institutional framework that expressly recognizes provincial and municipal autonomy, giving them at the same time a great deal of political authority especially in the decision-making process, Danish constitution only recognizes the existence of municipalities without any specification about their autonomy nor the role in delivering public policies. On the other hand, empirical testing shows much more decentralization in fiscal terms in Denmark than in Argentina. In comparing these two countries I will test my hypothesis which holding that the degree of fiscal autonomy is closely linked to the level of resources and expenditures available to subnational units of government, which does not necessarily correspond with the (unitary or federal) institutional framework, as defined in the constitutional text. Nevertheless, this institutional framework may appear as facilitator of decentralization. In others words, formal institutions matter less than formal institutions - standing out the difference between formal institutional settings and actual practices in Intergovernmental relations (IGR).

This article's main aim is to measure and compare institutional and fiscal decentralization in Argentina and Denmark throughout six indicators, which were elaborated on the basis of official data provided by governmental offices, as well as by OECD, World Bank and IMF. The methodology employed in this work is analytical and empirical regarding fiscal decentralization in each one of the selected case studies. On the one hand, this projects intends a comparative analysis between Latin-American and European countries, and on the other hand, between decentralized unitary and federal countries, comparing, therefore, fiscal decentralization in different institutional settings.

\section{MEASURING DECENTRALIZATION}

The study of decentralization implies to address the concept of autonomy of subnational governments. In this respect, autonomy is a construct susceptible to be measure through some indicators. These indicators are useful to measure the degree of decentralization vis-a-vis the fiscal autonomy of subnational governments. On the basis of data supplied by countries' official sources and international organizations (FMI, World Bank, OECD), I have elaborated a series of indicators - expressed in quantitative terms (percentages) - applied to characterized fiscal decentralization, to indicate its most particular specific characteristics and to highlight similarities and differences between the cases under study. This article intends to present some research findings based on the comparison of each of the six variables elaborated: (1) constitutional allocation of competences and powers; (2) Constitutional allocation of revenue-raising capacity; (3) Revenues directly raised by each level of government (excluding central transfers); (4) Transfer Mechanisms of central funds to subnational units and others form to finance subnational expenditure; (5) The total expenditure of each level of government combined; and (6) fiscal imbalance.

These six aspects of fiscal decentralization are will used as quantitative variables to measure the degree of subnational autonomy (expressed as percentage). The two first variables are legal and measure the degree of institutional decentralization. The remaining variables measure different aspects of decentralization and are elaborated

\footnotetext{
${ }^{5}$ See RodDEN (2004).
} 
with official data provided by countries and international organizations' official databases (such as OECD, World Bank and IMF).

In order to conceptualize the institutional structures, I rely in a legal/constitutional perspective, i.e., according to how territorial organization is defined in each country in their constitutional texts, as well as through legislative reforms (infra-constitutional) producing changes in the territorial organization. According to this classification, federalism do not necessarily mean more decentralization. Constitutionally unitary countries may have a degree of decentralization equal or even greater than federal countries. With this caveat in mind, the term "multilevel government" proposed by HOOGHE and MARKS ${ }^{6}$ is useful to refer decentralized countries, encompassing federal as well as unitary countries. They defined Multi-Level Government (MLG) as the dispersion of authoritative decision-making across multiple territorial levels. The broadness of the concept encompasses the idea of continuum describe above, and federal and unitary countries could be located in one point of the line according not to the formal institutional framework, but how task and functions are distributed and redistributed between levels of government.

\section{THE DEGREE OF DECENTRALIZATION IN ARGENTINA AND DENMARK}

The territorial organization of both countries recognizes three levels of government: central, intermediate and local. The last two are subnational levels. Intermediate levels in Denmark are the regions (regioners) or counties before the 2007 reform, and provinces (provincias) in Argentina. In both countries local tiers are called municipalities (kommuner in Denmark and municipios in Argentina). In both countries, the two subnational tiers have directly elected representatives. However, in Denmark they do not have institutional participation at the central decision-making arena, that is, in the national parliament, while Argentine provinces have representation both in the senate and the chamber of deputies (since the last one is divided in district coinciding with the provincial boundaries).

In unitary countries, intermediate and local levels are regulated by ordinary laws. This would suggest that decision-making remains at the central level only. In Denmark, article 82 of its Constitution - entitle "local autonomy" - prescribes "The right of the municipalities to manage their own affairs independently under the supervision of the State shall be laid down by Statute." This constitutional disposition has been unchanged since the Constitution of 1849. According to our theoretical framework, this constitutional disposition is a clear example of devolution type of administrative decentralization, since the central state transfers authority to subnational governmental levels by means of state legislation, which means that the political power to decide whether or not to transfer (o even to implement the service) remains, ultimately, at the central level of government. As a unitary country, subnational levels do not have autonomy guaranteed by the constitution.

However, Denmark has a long tradition of subnational self-government since the nineteenth century or even before". After the 1970 reform, and "following the amalgamations, a reform of local government functions was carried through over the next ten or twenty years. New tasks were transferred to local governments from the

\footnotetext{
${ }^{6}$ See HoOghe and MARKS (2001) and (2003).

${ }^{7}$ BLOM-HANSEN and HeEager (2011) p. 223.
} 
central government, and increased autonomy was introduced in the welfare areas that municipalities and counties already administrated"8. In 2007 a structural municipal reform took place, replacing the previous legislation from 1970. Therefore, there are two differentiated periods in the Danish case: 1970-2007 and 2007-2010. The reform of 1970 (in force until 2007) allocated more competences to subnational levels (municipalities and counties). In the 2007 reform "the old counties were stripped of almost all functions, which were divided between the central government and the new large municipalities"" .

Both reforms were legislatives, i.e., decided and implemented via central ordinary laws. The reform has three specific purposes: firstly, to reduce the number of regions and municipalities (passing from 271 to 98 municipalities and from 14 counties to 5 regions), secondly, to redistribute functions and tasks, and finally, the implementation of a new financing system. Regarding the territorial government structure, the reform implied an amalgamation of municipalities and regions. Concerning the functions and tasks, it allocated more functions to municipalities and to the central government, reducing simultaneously the functions of the (new) regions. Consequently, the expenditure share of the new regions decreased, and central and local shares increased.

The degree of institutional and fiscal decentralization in Argentina and Denmark is measure through six (quantitative) variables. They are summarized in Table 1.

Table 1. Degree of Decentralization in Argentina and Denmark.

All percentages in average between 2000 and 2010.

\begin{tabular}{|c|c|c|c|c|c|c|c|c|c|c|c|}
\hline & ( & & & & (3) & & (4) & & & (5) & (6) \\
\hline & Policy i & plem. & & ower & Own & & ral trar & & $(3)+(4)$ & Subnat. & VFI \\
\hline & $\begin{array}{c}\text { Genera } \\
1\end{array}$ & $\begin{array}{c}\text { Socia } \\
1\end{array}$ & No & $\%$ & Rev. & $\begin{array}{c}\text { Tota } \\
1\end{array}$ & $\begin{array}{l}\text { Non- } \\
\text { Earm }\end{array}$ & $\begin{array}{c}\text { Ear } \\
\text { m. }\end{array}$ & & $\begin{array}{c}\text { Spendin } \\
\text { g }\end{array}$ & \\
\hline Argentina & $58 \%$ & $86 \%$ & 4 & $11 \%$ & 18 & 60 & $48 \%$ & $11 \%$ & 48 & 49 & 0,37 \\
\hline Denmark & $42 \%$ & $86 \%$ & 6 & $20 \%$ & 30 & 41 & $18 \%$ & $32 \%$ & 59 & 62 & 0,48 \\
\hline
\end{tabular}

Considering both subnational levels: Argentina (provinces and municipalities) Denmark (Regions and municipalities)

(1) Percentage of Policy Implementation over a 19 policy areas.

(2) Subnational tax autonomy. Argentine municipalities actually do not levy any tax (despite the national and provincials constitutions recognize them tax autonomy). Regions in Denmark are no longer allowed to levy taxes since the 2007 reform. Still, the percentage of subnational levels remains the same.

(3) Subnational Tax resources, without central grants or transfers.

(4) A. Total Transfers as percentage of total subnational resources; B-C. Non-earmarked and earmarked central transfers as percentage of total subnational resources, both as percentage of total subnational resources.

(3) + (4) Overall amount of available subnational resources (own-resources plus central -non-earmarked and earmarked transfers) as percentage total country resources.

(5) Total subnational expenditure as percentage of total country (general government) expenditure.

\section{A) Competence Assignment. Distribution of tasks and competences between levels of governments}

The constitutional allocation of competences and powers measures the size of subnational government within the country. This variable intends to determine what competences correspond to each level of government according to the constitution (federal states) or legal dispositions (unitary states).

In the distribution of competences in both countries, central governments reserve for themselves the traditional functions related to defence, foreign affairs, army, economy (control of the money supply and of the financial system), etc., whereas subnational

\footnotetext{
${ }^{8}$ BLOM-HANSEN and HeEAGER (2011) p. 222.

${ }^{9}$ Blom-Hansen and HeEAger (2011) p. 224.
} 
units are in charge of implementation of social policy areas. In Argentina, eight competences are exclusively federal (42 per cent: international relations, armed forces, citizenship, issue currency, monetary and measures systems, telecommunications services, air and aerospace navigation foreign and interstate trade and communication); three are exclusive provincial (16 per cent: health, primary education and secondary and high education), eight are concurrent (26 per cent: labour policies, culture, education and science, environment, housing, formation of new subnational units, immigration and road).

In Denmark, eleven competences are exclusively central (58 per cent: formation of new subnational units, immigration, foreign and interstate trade and communication, police and security services), six are exclusive subnational competences (37 per cent): three (16 per cent) are regional (health, secondary and high education and road) and four (21 per cent) are municipal (labour policies, culture, education and science, primary education and housing). Finally, one is concurrent between central and subnational regional ( 5 per cent: environment). After the 2007 reform, only one competence remains in the hands of regions (health), and it is not exclusive, rather is shared with the central government. Municipalities, in turn, increased their competences from four to six: they are now in charge of Immigration (previously central) and road (previously regional).

Eight of those competences are classified as social policies: in Argentina, three are concurrent ( 38 per cent), one is shared (13 percent), three are exclusively provincial (38 per cent) and one is federal (13 per cent). In conclusion, over social policies, provinces are in charge of most of them: they have implementation over 88 per cent. In Denmark, subnational units are in charge to implement six over seven. Between them, health is a divided policy between municipalities and regions (being the regions in charge only of hospitalization services). Danish Subnational levels are in charge of implementing 85 per cent of social policies, and only 15 per cent the central government (secondary and university education -recentralized in the 2007 reform, passing from the former counties to the central government). Considering both, exclusive subnational and concurrent competences, subnational units in Argentina are in charge of 58 per cent of general public policies, and 42 per cent in Denmark. Regarding social policies, both countries show the same percentage: 86 per cent. Subnational units are endowed with a wealth of authority, making a highly decentralized countries at the political and/or institutional aspect.

\section{B) Tax Power Allocation}

The Constitutional allocation of revenue-raising capacity between levels of government is an institutional variable that measures the formal or institutional decentralization of autonomy's fiscal aspect and the scope of provincial power taxation. It seeks to determine what kind of taxes are constitutionally or legally assigned to each level of government. Taxation power represents the genuine resources subnational governments could enjoy, and the consequently freedom to expend them. The formal or institutional decentralization of autonomy's fiscal aspect refers to tax autonomy concept, understood as "the various aspects of the freedom sub-central governments have over their own taxes" $" 10$.

${ }^{10}$ OECD (1999): “Taxing powers of state and local government”, OECD Tax Policy Studies № 1. 
In principle, in Denmark taxing power remains at the central government, since the constitution do not provide any tax power to a different level of government. All taxes (central and local) are legislated by national laws, and collected by central government. As in the rest of Scandinavian countries, "financing is centralized and dominated by regulated income tax revenue sharing and central government grants" ${ }^{\text {"11 }}$. The 2007 reform further centralizes this competence: among the functions that were highly centralized, it was included tax administration, "which was a shared responsibility before the reform and now is a fully centralised function under the Ministry of Taxation" ${ }^{\prime 2}$. However, in the evolution of the Danish system of tax financing, central government allowed municipalities and counties to set freely the rate of income taxes (corporate income taxes and several personal income taxes). Danes municipalities have some degree of autonomy regarding taxes on certain public corporations and the Municipal land tax (market value), in which the tax base is set in national legislation, but tax rate is set by the municipalities; Personal income taxes and most of the corporate taxes are shared between central government and municipalities. In these taxes, tax base and tax rates are set in legislation and central government is legally free to change both the tax base and the rate, although that never happen in practice without previous negotiations and an explicit consent of local governments.

Before 2007, Counties had some degree of tax autonomy, yet minimal. They were able to set the rate tax of personal income tax and they share a percentage of property taxes (market value) and the counties' property tax, but "the tax base of the property taxes (market value) and the tax rate for the counties' property tax are defined in legislation" $(1 \text { percent of property tax })^{13}$. Currently, and after the 2007 reform, the new regions (the former "counties") do not have any power taxation.

Considering each taxes individually, in many of the direct taxes municipalities have some degree of autonomy: property tax, tax on the value of land (land tax) and corporate taxes. The central state levies direct taxes as health contributions, labour market contributions and property value tax, and almost all indirect taxes, such as value added tax (VAT), green taxes, excise duties and customs duties. Municipalities also levy fees and duties (such as duty on building certificates, some fees including publican's licenses and entertainment taxes - e.g. on slot machines -, duty for meat and foodstuff control). Most of these fees are fixed in legislation or subject to some restrictions, such as an upper-bound, set in legislation ${ }^{14}$. However, they represent a very low percentage in local budgets.

As in many federations, Argentine constitution adopts a current tax system regarding internal taxes. According to the constitution, provinces are endowed with power to levy

\footnotetext{
${ }^{11}$ See RATTS $\varnothing$, Jørn (2005): “Local tax financing in the Nordic countries”, Economic General Report for the 2004 Nordic Tax Research Council meeting in Oslo, forthcoming in Yearbook for Nordic Tax Research, avalaible in http://www.svt.ntnu.no/iso/jorn.rattso/Papers/jrnordictax.pdf, date of access: March 8, 2018.

${ }^{12}$ LGDK [Local Government Denmark] (2009): “The Danish Local Government System”, p. 22, available on: http://www.kl.dk/ImageVaultFiles/id_38221/cf_202/Background_Paper__Local_Government_in_Denmark.PDF, date of access: March 7, 2018. From 1 November 2005 until 2007, "the formerly divided Danish tax administration became a unity administration joint in the Ministry of Taxation". The tax administration consisted of a state tax administration with regional offices and a municipal tax administration (OECD, n.d., p. 12).

${ }^{13}$ OECD (1999): "Taxing powers of state and local government”, OECD Tax Policy Studies N ${ }^{\circ}$ 1, p. 32.

${ }^{14}$ OECD (1999): "Taxing powers of state and local government”, OECD Tax Policy Studies $\mathrm{N}^{\circ} 1$, p. 33.
} 
direct and indirect internal taxes. The exercise taxing power over indirect taxes (the Value Added Tax among the most important) is concurrent with the federal government (Art. 75.2), whereas the federal taxing power over direct taxes (income tax, property tax) is only an exceptional competence. According to Art. 75.2 federal government is authorized to levy direct taxes for a specified term and proportionally equal throughout the national territory, only when the defence, common security and general welfare of the State so require it. In spite of this constitutional mandate, federal government has created and collected direct taxes in a permanently and continuously fashion since 1930 to present. Art. 75.1 attributes exclusively to the federal government the power to lay import and export duties, being forbidden to provinces (Art. 126). However, Argentine provinces actually levy a few taxes as exclusive competence (only four taxes). This is because specific agreements through intergovernmental coordination during the 90 s.

Just the opposite of the Danish case, in where informal (non-institutionalized) agreements and negotiations between levels of governments allow subnational units to enjoy more financial power over the years, in Argentina the agreements celebrated between the federal government and provinces were utilized to restrain provincial and municipal power taxation, centralizing tax legislation and tax collection in the central level.

In short, the current and practical assignment of revenues in Argentina is as follows: federal government recollects: (a) income tax; (b) VAT; (c) Excise taxes; (d) import and export duties; (e) liquid fuel and energy taxes; (f) gross assets tax; (g) personal assets tax; (g) social security taxes (just to mention the most important). Provinces in turn collect the following (only) four taxes: (a) automobile taxes; (b) tax on immovable property; (c) stamp duty and (d) gross receipts tax ${ }^{15}$. Municipalities only collect charges and administrative fees, even though the national and provincial constitutions recognize them a broad tax power. This is mainly a consequence of coordination between federal and provincial governments on fiscal authority distribution. In general, federal government collects all taxes (which are subject to revenue sharing with provinces), except those four taxes which are currently collected by provinces and import and export duties.

To measure tax autonomy, I follow OECD 1999 taxonomy of subnational tax autonomy. Argentine provinces fall into the Category A.1 regarding all internal taxes (direct and indirect taxes), and Category $\mathrm{F}$ regarding import and export duties, while Danish municipalities fall into Category B (Municipal land tax and tax on certain public corporations) and into Category D.3 (Personal income tax and corporate taxes). As we can observe, tax autonomy in Denmark is limited at the institutional level. Municipalities have no freedom to introduce (or to abolish) any tax or to define the tax base, but only to set the tax rate over some kind of taxes (categories B and D). However, the real functioning of the financing system is quite different from institutional design in both cases.

Regardless the institutional framework, actually subnational levels in both countries have limited autonomy in a lower percentage comparing with central levels. In Denmark, despite the central government is legally able to unilaterally change tax legislation (tax and rate tax) and the share of subnational government, this did not happen without previous negotiations with municipalities, and they share much of the

\footnotetext{
${ }^{15}$ See SchWARTZ and LiUKSILA (1997).
} 
most important taxes. Considering that municipalities do not enjoy institutional autonomy over taxation, in practice they have some degree of autonomy over six individual taxes over a total of thirty current taxes in the country (a twenty percent). In Argentina, although constitution recognises subnational tax autonomy, in practice provinces only levy four taxes over 35 current taxes in the country and municipalities do not recollect any tax - only charges and administrative fees ${ }^{16}$. The reaming internal taxes (direct and indirect taxes) are levied by the central government, but ultimately shared with provinces through a shared system, known as coparticipation regime, in which central government legislate and recollect most of the taxes and subsequently it shares some percentage with provinces. As this regimen is considered as a transfer in national and provincial budgets, I will analyse it in "transfers" section.

Both outcomes were reached through agreements, however, while in the Danish case those agreements sought to increase local tax autonomy, in Argentine case, provinces have preferred centralized tax administration (self-limiting their own taxation power). Subnational levels in Argentina enjoy autonomy over a limited number of taxes (eleven per cent) comparing with the Danish case.

\section{C) Subnational Own-Resources}

Variable three intends to capture the amounts of resources that are genuinely subnational. This excludes transfers or grants derived from the central government. In other words, this variables considers the actual exercise of fiscal power, which may be different as provided by the institutional setting. As we can observe in Table 1, column 3 subnational governments in Denmark almost double argentine subnational governments, considering in both cases intermediate and local governments.

In the evolution of 2000 decade, subnational governments' share in Denmark shows an average of 30 percent. The table shows a decrease since 2007, passing from 31 per cent in 2006 to 24 per cent in 2007, and since then it rises again. Only in 2007, local governments decrease seven points in their own-resources. This is due mainly to the 2007 reform, which took apart resources from regions and redistributed them between central and local governments. Argentine subnational governments instead show a continue declining line, ranging from 22 per cent in 2000 to 18 per cent in 2010, losing 4 per cent of own resources, with an average of 18 per cent. There is a striking difference between municipalities and regions regarding provincial and municipal level in Argentina and Denmark, respectively. In average, Danes municipalities represented 23 per cent, while regions 7 per cent (cero per cent since 2007), Argentine provinces 18 per cent, while municipalities only 0.3 per cent.

\section{D) Transfers Systems}

Variables 2 and 3 do not show the total revenues at subnational levels' disposal. Due to the process of decentralization operated in most countries, the fiscal structure and intergovernmental relations gets more complexity, and consequently a series of different mechanisms of intergovernmental transfers are required. They existence becomes necessary in order to fix fiscal autonomy with policy decentralization. In this section, I will first analyse (1) the transfers system in each country, considering the percentages of total central transfers according to the type of grants; Second, (2) total subnational

\footnotetext{
${ }^{16}$ It is true that in some provinces, municipalities are allowed to collect some taxes or they share some provincial taxes, but the general principle is that municipalities do not introduce any tax.
} 
resources after transfers as a share of subnational and central total resources; And thirdly, (3) I will consider transfers by type according to each kind of subnational units.

There are of two kinds of central transfers: earmarked and non-earmarked. Earmarked funds affect the expenditure autonomy of subnational governments, since these funds must be spending on specific tasks previously decided by the central government. Nonearmarked are not condition to any specific purpose, increasing consequently the degree of subnational autonomy spending.

\section{(1) Subnational Resources (own-resources plus transfers) as percentage of total country resources}

Argentine provinces increased their amount of total revenues at their disposal (including own resources) up to 48 per cent regarding the federal government in average between 2000 and $2010^{17}$. According to SCHWARTZ and LIUKSILA, between 1991 and 1995, percentages were similar as in the previous decade ${ }^{18}$. Subnational units in Denmark, instead, increase their total amount of resources up to 59 per cent in average - almost ten points of difference with Argentina. Adding transfers to own subnational levels' resources, subnational levels significantly increase their total amount of resources at their disposal nearly the double. Both subnational levels in Denmark increase from 30 per cent up to 59 per cent in average between 2000 and 2010, whereas the central level shows a proportional inverse trend (from 70 to 41 per cent).

\section{(2) Transfers by type}

Despite the increasing in resources due to central transfers, it is necessary to consider the nature and type of these grants. Earmarked and non-earmarked grants makes a difference in the degree of subnational spending autonomy. There is a significant difference between both countries regarding the type of central grants: In Argentina, provinces enjoy more spending autonomy since non-earmarked grants represent in average 48 per cent of total subnational resources ( 65 per cent of total federal transfers), whereas non-earmarked grants in Denmark represent 18 per cent of total subnational resources ( 35 per cent of total central transfers). This autonomy ultimately translates into more power decision-making regarding their available resources.

In Denmark, we find important changes after the 2007 municipal reform. As stated before, one of the main aims of the reform was to remove regional taxes and to introduce one general block grant, replacing the existing grants. Regarding regions, since they cannot impose taxes, depend only on central grants. Consequently, regions are financed by a central government grants and in some extent by municipalities through a small contribution when its inhabitants utilize the regional care system ${ }^{19}$. In 2007 central grants surpass subnational own resources, reversing the relationship from

${ }^{17}$ Data from 2012. Compilation based on National Direction of Fiscal Coordination with Provinces, Ministry of Economy of Argentina, databases, www.mecon.gov.ar/hacienda/dncfp/ and OECD Statistical Database, http://stats.oecd.org/.

${ }^{18}$ SCHWARTZ and LIUKSILA (1997) p. 390.

19 "All Danish inhabitants pay a recent introduced health tax $(8$ percent of the taxable income) to the central government which partly finances the central government grant to the regions" (LGDK [Local Government Denmark] (2009): "The Danish Local Government System", p. 15, available on: http://www.kl.dk/ImageVaultFiles/id_38221/cf_202/Background_Paper__Local_Government_in_Denmark.PDF, date of access: March 7, 2018 p. 15). 
46 per cent of grants and 54 per cent of own taxes in 2006 to 58 per cent of grants and 42 per cent of own taxes in 2007. Since then, central grants systematically increase their share up to 61 per cent in 2010.

Regarding non-earmarked grants, there were a systematically increase since 2007, whereas earmarked grants remains unchanged. Non-earmarked grants increased ten per cent in only one year, from 15 per cent up to 25 per cent and reaching a 29 per cent (almost a double) in 2010. On the contrary, earmarked grants range between 31 and 33 per cent. Comparing the total amounts of earmarked and non-earmarked grants, we can observe, on the one hand, a trend in which both types of grants tend to be equated (in percentage of total grants amounts) and, on the other hand, an increase in total amount of grants transferred (in billions of krones).

\section{(3) Central grants by level of Government}

Central grants transferred to regions decrease in percentage terms from 71 per cent in 2000 to 64 per cent in 2009. However, the total amount in billions of Danish krone significantly increase in 2007, from 127 billion of kr. in 2006 up to 174 billion of kr. in 2007. These variations are due to two significant changes regarding the role of region in the public sector: First, regions are no longer able to levy any kind of tax and secondly, the 2007 reform removed some regional competencies (being transferred to the central and/or the municipal level).

\section{E) Spending power}

Decentralization of public spending is a worldwide trend, even in unitary countries ${ }^{20}$. In Argentina, the most important turning point in the evolution of public expending between levels of governments occurred at the beginning of the 1990s, when federal government decentralized some competences - particularly, education and public health. Provinces increased their public expenditure from $25 \%$ in 1986 to $38 \%$ in $1994^{21}$ - just after the decentralization process mentioned above had operated. This trend has maintained over the following decades, in where subnational units represent 49 per cent in average between 2000 and 2009 (considering both intermediate and local levels). Under the period of analysis, in 2006 provinces reached the highest percentage in public expenditure ( 52 per cent), however, since then the trend begins to decrease to 48 per cent in 2007, 47 in 2008 and 46 in 2009 (see Graph 5.1). Municipalities, however, have maintaining a share of $8-9$ per cent during the whole period.

This downward trend corresponds to a change in state model since 2003, passing from a neoliberal state (introduced in the 90s) to a more interventionist state. Consequently, federal government began to be more engaged in public expenditure. These percentages assimilate Argentina with other decentralized federations, such as Germany (38) and Switzerland (39) ${ }^{22}$. According to the data processing based on OECD database, subnational levels in Denmark represent in average 62 per cent between 2000 and

\footnotetext{
${ }^{20}$ See RoDDEN (2004).

${ }^{21}$ See World Bank Report Argentina: Provincial Finances Study: Selected Issues in Fiscal Federalism, Vol. I., p. 5, available on: http://documents.worldbank.org/curated/en/267001468767403555/pdf/multipage.pdf, date of access: March 7, 2018.

${ }^{22}$ SWENDEN (2006) p. 109.
} 
$2010^{23}$. Regarding the subnational share of expenditure in the Danes case, different sources show similar percentages: MAU shows 62 per cent in $2007^{24}$, MORTENSEN indicates 61.8 in $2005^{25}$, and OECD around $63.8^{26}$ and $62^{27}$, whereas BLOM-HANSEN and HEEAGER fit local functions amounts to two-thirds of all public expenditure ${ }^{28}$.

The difference between both countries is striking. The average reached by Denmark in 2000-2010 period is 62 per cent, whereas subnational governments in Argentina reached 49 per cent, a difference of thirteen points. Between 2006 and 2010, when subnational governments in Argentina began to lose points in their share of total public expenditure, the difference with Danish subnational levels rises up to 20 percent.

As we seen in the previous section, in Argentina only a few transfers are conditioned to specific purposes: "Still, provinces and local jurisdictions enjoyed significant autonomy with respect to the amount, structure, execution, and supervision of various social services, including housing and education (except university)" ${ }^{29}$. In addition, most of the constitutional competences are concurrent between federal and subnational levels, especially those that revolve around the idea of a welfare state model. The competencies that encompasses this model of state focus on social policy areas, typically health, education, social security, housing, sanitation policies and the newest ones, such as environment and consumer protection.

Through different process of decentralization, the federal level delegated the administration and implementation of these policies ${ }^{30}$, while it reserved the financing and establishment of general and nationwide minimum standards - however, those standards must be agreed with provinces before being implemented in their jurisdictions. This logically increased subnational share on consolidated public expenditure, and explains that the rise of subnational expenditure was inversely proportional to the decrease of federal spending on the same areas. 56 per cent of subnational budgets are destined to social services (as average, between 1991 and 2009). And within this category, health represents 10.5 per cent and education 30 per cent, housing policies 4 per cent, promotion and social assistance 5 per cent and social security 2.7. In turn, municipalities have most of their share of public expenditure focused to urban services: 96.4 in 1986 and 93.3 in $1996^{31}$.

\footnotetext{
${ }^{23}$ Regarding the subnational share of expenditure in the Danes case, sources show similar percentages: MAU (2010) p. 289 shows 62 per cent in 2007, MORTENSEN (2014) p. 87 indicates 61.8 in 2005, around 63.8 (OECD 2011) or 62 (OECD 2013), BLOM-HANSEN and HEEAGER (2011) p. 227 whereas others fit local functions amount to two-thirds of all public expenditure.

${ }^{24}$ MAU (2010) p. 289.

${ }^{25}$ Mortensen (2014) p. 87.

26 OECD (2011): "Government at a Glance 2011. Country Note: DENMARK", available on http://www.oecd.org/denmark/47876326.pdf, date of access: March 9, 2018.

27 OECD (2013): "OECD Regions at a Glance 2013 - Denmark Profile", available on: http://rag.oecd.org, date of access: March 7, 2018.

${ }^{28}$ BLOM-HANSEN and HeEAGER (2011) p. 227.

${ }^{29}$ See SCHNEIDER (2004), see also GARMAN et al. (2001) p. 215.

${ }^{30}$ Before the transfer processes took place, both educations and health functions were performed by the two levels in a parallel fashion.

${ }^{31}$ See World Bank Report Argentina: Provincial Finances Study: Selected Issues in Fiscal Federalism, Vol. I, p. 5. avalaible on: http://documents.worldbank.org/curated/en/267001468767403555/pdf/multipage.pdf, date of access: March 7, 2018.
} 
Denmark, in turn, "has one of the largest public sectors in the world - in relative terms" ${ }^{, 32}$ and most of the welfare services are provided by subnational units, especially municipalities since 2007. Central government collects almost $70 \%$ of revenues but represents about $32 \%$ of expenditures, "suggesting that most goods and services are provided by local governments-often using revenues transferred from the central level"33. 43 per cent of general government public expenditure was devoted to social protection, following by health $(15$ per cent $)$ and education $(13 \text { per cent })^{34}$. At the subnational level, 78 per cent of subnational pubic investment was allocated to social protection $^{35}$.

\section{F) Vertical Fiscal Imbalance}

Fiscal imbalance arise when subnational governments do not raise enough resources to cover their expenditure needs ${ }^{36}$. In terms of ALDASORO and SEIFERLING, "Vertical fiscal imbalances attempt to measure the extent to which subnational governments' expenditures are financed through own revenues rather than transfers from the central government or borrowing by the subnational governments." ${ }^{, 37}$ Fiscal imbalance could be vertical or horizontal. Horizontal fiscal imbalance appears when insufficiency to cover the public expenses differ between subnational units. This may occur when regional taxes are unequally spread or when per capita revenues and expenditures vary strongly from one unit to another ${ }^{38}$. There are, of course, others factors contributing horizontal imbalance, such as the geographic characteristics of subnational units, population, etc.

Fiscal imbalance is vertical when this subnational insufficiency is regarding the federal or central level. In the present article, I focus in vertical fiscal imbalance (VFI) only. Despite there is no consensus regarding the way to measure vertical fiscal imbalances ${ }^{39}$, I have taken (following Swenden 2006 work) the average of subnational own-resources prior federal/central transfers as percentage of total country revenue and the percentage of subnational public expenditure after transfers as percentage of total country public expenditure (leaving aside the borrowing capacity of subnational units), all those data as average between 2000 and 2010. VFI index arises as the ratio of total revenues and public expenditure according to the available official data gathering from Countries' Ministry of Economy and OECD databases. According to Swenden, when the ratio obtained is lower than 1.0, means that subnational units do not cover their expenses with their own resources (i.e., locally raised taxes). Conversely, if ratio exceeds 1.0 means that subnational governments receive more money than they expend ${ }^{40}$. A ratio of 1.0 indicates a perfect vertical balance.

32 MAU (2010) p. 287; see also OECD (2011): "Government at a Glance 2011. Country Note: DENMARK", available on http://www.oecd.org/denmark/47876326.pdf. date of access: March 9, 2018, see RODDEN (2004).

33 OECD (2011): "Government at a Glance 2011. Country Note: DENMARK", available on: http://www.oecd.org/denmark/47876326.pdf. date of access: March 7, 2018. Danish government employs 28 per cent of the labour force (in 2008), corresponding 76.20 per cent to subnational levels.

34 Ibíd.

${ }^{35}$ OECD (2013): “OECD Regions at a Glance 2013 - Denmark Profile”, available on: http://rag.oecd.org, date of access: March 7, 2018

${ }^{36}$ See SWENDEN (2006).

${ }^{37}$ ALDASORO and SEIFERLING (2014) p. 6.

${ }^{38}$ See SWENDEN (2006).

${ }^{39}$ See ALDASORO and SEIFERLING (2014).

${ }^{40}$ SWENDEN (2006) p. 112. 
VFI is higher in Argentina than in Denmark. That means provinces in Argentina are responsible for a high percentage of consolidated public expenditure but at the same time, they lack own resources to afford those expenditures. The difference between both countries is significant: 0.37 in Argentina against 0.48 in Denmark, a difference of almost ten points. However, the degree of VFI reached in both countries means that federal and central governments in both countries have decentralized spending more than revenues ${ }^{41}$. In any case, VFI is a useful index to confirm the dependence of subnational governments on federal or central transfers to afford their responsibilities. These findings confirm the general trend, as to which VFI is common in most of countries.

\section{CONCLUSION}

This paper attempts to highlight is the specific differences (and similarities) with a country from a different region and with a totally different institutional framework, analysing each of the most important variables within the broad concept of decentralization and figure out the factors underling those numerical indicators. According to Table 1, Denmark is more decentralized than Argentina in almost all indicators, except from the participation of subnational units in the implementation of general public policies (58 per cent in Argentina against 42 per cent in Denmark). The other difference are the amounts of non-earmarked transfers.

These empirical evidence has demonstrated that a unitary country (Denmark) is much more decentralized than a federal one (Argentina). Previous works have pointed out the high degree of decentralization that not only Denmark, but also the Scandinavian countries, have achieved, concluding that their degree of decentralization is even more high than federal countries in the world. Other scholars has reached similar conclusions (RODDEN ranked Denmark as the third-most decentralized country in a sample of 29 countries and OECD's works have achieved the same conclusion regarding the OECD countries $\left.^{42}\right)$.

A first important conclusion is that federalism does not mean decentralization. Institutional decentralization does not always coincide with the actual degree of decentralization. This fact suggests the differences between formal institutions and actual practices. In both cases, informal institutions seem to be more important than formal institutions ${ }^{43}$. For instance, in Denmark the associations of local governments and the patterns of negotiated agreements between levels of governments are not contemplated neither in the Constitution nor in the ordinary legislation. However, these agreements have preceded every decentralization process. As BLOM-HANSEN has stated, "the arrangement was not formalized but consisted of informal negotiations between the central government and local government representatives" 44 .

\footnotetext{
${ }^{41}$ See EYRAUD and LUSINYAN (2011).

${ }^{42}$ See RODDEN (2004).

${ }^{43}$ Informal institutions are defined by HELMKE and LEVITSKY (2004) p. 727 as "socially shared rules, usually unwritten, that are created, communicated, and enforced outside of officially sanctioned channels".

${ }^{44}$ BLOM-HANSEN (1998) p. 148.
} 
Moreover, in Denmark - as a unitary country - formal institutional framework does not account with any institutional provision of subnational units' participation at the central decision-making arena nor the parliament constitution is based on territory, i.e., electoral districts do not correspond to the boundaries of territorial governments. If such is the case, "more territorial bargaining might be expected than in systems without districts" 45 . This means that subnational levels do not have institutional veto over central decisions. However, contrary to Rodden's opinion, and despite that in the Danish political system no territorial unit plays a formal role in the central government's decision procedure, subnational levels (especially municipalities) have been successful in achieving more decentralization. The political organization of Denmark is characterized by the "use of agreements as an alternative to parliamentary regulation" 46 , in which local governments associations (such as the Local Government Denmark agency) have a privileged position, despite that their agreements are not legally binding for local governments members. Denmark, however, shows some "federal practices", especially regarding the preceding negotiations before the operation of any change in the vertical distribution of policies and competences. This particular practice have being highlighted by several scholars, and given the importance that local associations have acquired in these processes over time, they were defined as the "second chamber" 47 . These federal practices turn the Danish polity in a federal one. However, considering the way in which decentralization took place, an administrative decentralization with a strong control and supervision from the central government, rather than political decentralization would be the most proper way to classify the Danes case. Regions, on the contrary, had never played any important role. That was pointed out with the 2007 reform. It is clear that the level that matters in the Danes system is the local one. This is interesting regarding the "informal" federalist system we mentioned earlier - It would be possible to constitute a municipal-based federal system?

In Argentina, provinces have had an undisputed role in the process of decentralization. Despite that the process would seem to have a top-down trend, provinces ultimately must accept the competences transferred. The federal government in Argentina could be characterized as the first mover in negotiation processes, a situation of decision-making similar to that described by the battle of the sexes or the Stackelberg's followers in game theory ${ }^{48}$. According to the pattern of negotiations process (most of them, after the decision of the central government to decentralized), provinces have preferred a political decentralization (decision-making autonomy over public policies) with a strong funding from the national government.

From a federal perspective, and considering the results of this work, "federalism does not necessarily entail greater independent authority for subnational governments over taxes, expenditures, or anything else" 49 , therefore, "not always unitary countries have a centralized government or, inversely, federal countries have a decentralized one" $"$. Indeed, many federal countries has a very low degree of subnational tax autonomy ${ }^{51}$.

\footnotetext{
${ }^{45}$ RODDEN (2004) p. 490.

${ }^{46}$ BLOM-HANSEN (2010) p. 244.

${ }^{47}$ LGDK [Local Government Denmark] (2009): “The Danish Local Government System”, p. 11, available on: http://www.kl.dk/ImageVaultFiles/id_38221/cf_202/Background_Paper__Local_Government_in_Denmark.PDF, date of access: March 7, 2018.

${ }^{\overline{48}}$ See Altavilla (2016).

${ }^{49}$ RodDEN (2004) p. 493.

${ }^{50}$ Dziobek, GutiÉRrez MANGAS and Kufa (2011) p. 25.

${ }^{51}$ See RodDEN (2004).
} 
Argentina fits within this classification, and what is most striking is that subnational units consented these outcome. Despite that constitution in Argentina allocates most of the competences as concurrent and several dispositions tend to prevent federal imposition, subnational units have resigned much of their constitutional powers. A possible causal explanation could be the high asymmetries between provinces, in which most of them have a degree of development much lesser than other few provinces and its logical preference is redistribution of fiscal resources from the center rather than more fiscal or tax autonomy.

\section{a. The Role of Subnational Governments in Decentralization Processes}

According to Rodden "federalism is not a particular distribution of authorities between governments, but rather a process - structured by a set of institutions - through which authority is distributed and redistributed" ${ }^{\prime, 5}$. The idea of contract or covenant between different states arises, meaning that the parties involved must fulfil some obligation to one another: "If central government can get everything it wants from local governments by simple acts of administrative fiat, it makes little sense to see the two as engaged in a contractual, or federal, relationship" ${ }^{\text {. }}$.

The author also highlight the importance to underline how and why federal contracts are made in the first place. A top-down decentralization is expected to be the case in a unitary system. However, the Argentine federalism - in which and in theory, the process of decentralization should take a bottom-up tendency - experienced process of decentralization with the same top-down trend. The 1970 process of decentralization was made by a de facto government and the 1992 process of decentralization was practically imposed to provinces, in both cases, consultation and negotiation with provinces was scarce, in a "mix of conviction, foreign pressure, political opportunism, and shortsighted fiscal moves" 54 .

Denmark, like the rest of the Scandinavian countries, shows a long-rooted tradition of decentralization of functions and competencies - with important antecedents between 1945 and 1970. A further decentralization took place in late $1970^{55}$ and "paved the way for a massive transfer of functions from the central government to the new municipalities and countries, concurrently with the expansion of the Danish welfare state" ${ }^{, 56}$. Following the latest municipal reform of 2007, the level of municipal autonomy was strengthened even more ${ }^{57}$, but at the same time, the process brought with it a greater financial control exercised by central government. Nevertheless, even in this aspect, the control was exercised through annual agreements with local governments in a system known as "budgetary cooperation",58 within the traditional Scandinavian "corporatism"

\footnotetext{
${ }^{52}$ RODDEN (2004) p. 489.

${ }^{53}$ Ibíd.

54 TOMMASI (2002) p. 68.

55 In the 1960s the level of subnational public expenditure was similar to other European countries (BLOM-HANSEN (1998) pp. 130-131).

${ }^{56}$ BLOM-HANSEN (1999) p. 244.

57 MIH [Ministry of the Interior and Health] (2010): "The Local Government Reform - In Brief" Published by the Ministry of the Interior and Health, Department of Economics. Available on: www.im.dk, date of access: March 7, 2018.

${ }^{58}$ See BlOM-HANSEN (1998) and (1999).

${ }^{59}$ See PiCARD (1983).
} 
currently delivered by local governments, and all these tasks are highly decentralized ${ }^{60}$. All in all, Danish municipalities eventually came to deliver almost all welfare services the Danish welfare state is, therefore, a local welfare state. In all these reforms, at the same time, the central government laid down the general framework ${ }^{61}$.

Argentina, on the contrary, has experience a process of centralization or recentralization in some important areas, especially in fiscal terms. This is also a distinctive feature in Latin-America $^{62}$. The introduction of state welfare model in 1940 gave prevalence to the central government in decision-making, implementation and financing public policies, as it was the case in United States during the New Deal. However, since the decade of 1970 some processes of decentralization took place in two important areas of social policies: education and health care. This processes were deepened in the beginning of 1990, were federal government fully decentralized the implementation and decisionmaking of these two social policies. Since then, provinces are in charge of delivering and financed most of the social policies areas: education, health care, housing policies, whereas the federal government reserved to itself the role of financing and the establishment of nationwide minimum standards.

Going back to the basics of IGR in Denmark, the 1970 reform meant a turning point in which IGR started from scratch ${ }^{63}$. The decentralization process followed a top-down trend, but starts in the very beginning with robust patterns of negotiation, balancing central control and local autonomy. Consequently, and according to BLOM-HANSEN, the reason for the choice of a cooperative strategy rather than a coercive control from the center "cannot be found in institutional legacies" ". In this seminal moment of Danish IGR, the local government associations "seem to have been opposed to the idea [of central control], but accepted cooperative means of control as the lesser of two evils" Most important is that these informal practices were rooted in a long time period and they seem strong enough to prevent some modifications from the central level unilaterally - despite that the central government has the authority to do it.

On the other side of the coin, these processes unveiled that municipalities' functions were designed according to the central government's needs: in all processes, central government was free to shape local government according to its perceived needs ${ }^{66}$. While this process brought more local autonomy, at the same time implied more control from the center: "Denmark is the third-most decentralized country in the world [...] even more decentralized than the United States - though the central government tightly regulates virtually every aspect of local finance" ${ }^{\circ 7}$.

In Argentina seems more evident that subnational units preferred more expenditure decentralization rather than more tax autonomy. Indeed, provinces have voluntarily resigned to their constitutionally guaranteed autonomy tax, in order to allow federal

\footnotetext{
${ }^{60} \mathrm{MIH}$ [Ministry of the Interior and Health] (2010): “The Local Government Reform - In Brief" Published by the Ministry of the Interior and Health, Department of Economics. Available on: www.im.dk, date of access: March 7, 2018.

${ }^{61}$ Ibíd.

${ }^{62}$ See JORDANA (2002).

${ }^{63}$ BLOM-HANSEN (1998) p. 152.

${ }^{64}$ Ibíd.

${ }^{65}$ BLOM-HANSEN (1998) p. 151.

${ }^{66}$ BlOM-HANSEN and HeEAGER (2011) p. 225.

${ }^{67}$ RodDEN (2004) p. 483.
} 
government to levy almost all taxes in the country. These agreements implied a resignation of their respective municipalities too. But at the same time, provinces gained in political autonomy, being free to decide which policies implement and how. A key factor could be found in the horizontal asymmetries that characterized this federation. After these agreements, provincial taxation power only represent 18 per cent of total country fiscal resources. However, provinces have managed to get more federal resources which are to a large extent not targeted to any specific purpose. While provinces gain in political decentralization in exchange for fiscal centralization, municipalities - without a say in the process - lost in both aspects. They lost virtually their tax autonomy and remain highly dependent on provincial resources.

Another factor explaining decentralization in Argentina in the recent decades were the increasing international pressure to decentralize governance. In general terms, federal government decided to transfer public policies to provinces in order to fill international conditions for borrowing international grants and to stabilize federal public finances. In turn, provinces agreed in decentralize public policies that would be translated in more political power, however, with less fiscal autonomy. Federal and provincial (at least the majority of them) preferences were aligned in this equilibrium point. This explanation can be applied not only to understanding recent decentralization (as well as recentralization) processes ${ }^{68}$, but also the very origin of the Argentine federation ${ }^{69}$.

\section{b. The intergovernmental dilemma: between central control and local autonomy}

According to the previous statement, subnational units in Argentina (mainly, provinces) are less controlled by the central level than Danish subnational units are (municipalities). Subnational levels in Denmark are in charge of implementing and partially finance almost all social policies. However, in doing so they have to fit to central government general standards.

When decentralization of competencies to subnational units occurred in Denmark, a simultaneous economic deterioration was followed, and that fact pushed central government to put interest in control the macroeconomic situation, by controlling local governments ${ }^{70}$. However, worthy of note is that macroeconomic control was carried out through agreements with local governments associations, in a system known as the "budgetary cooperation". Moreover, central government has never impose coercive measures to local governments (and only with very few exceptions), instead periodical negotiations has been used, at least from $1970 \mathrm{~s}^{71}$. In short, Denmark, like the "Scandinavian countries have been able to radically decentralize their public sectors without losing the ability to control macroeconomic performance through public income and expenditure" establishing institutions "to coordinate economic activity levels at the local level with macroeconomic policy goals at the central level",72.

A key factor to better understand whether or not subnational units enjoy political authority, would be determine which level of government has decision-making authority. This is difficult to measure. However, in general terms, central government in

\footnotetext{
${ }^{68}$ See Altavilla (2016) and (2015).

${ }^{69}$ See GiBSON and FALLETI (2004).

${ }^{70}$ See BLOM-HANSEN (1998).

${ }^{71}$ See Blom-Hansen (1998).

${ }^{72}$ BLOM-HANSEN (1998) p. 152.
} 
Denmark has the power to impose its desired policy goals. There is an "intergovernmental dilemma" in which "local governments have a certain degree of autonomy at the same time as the central government has relatively clear policy goals. This means that if central guidelines are to be implemented, lower levels of governments must be coaxed or forced to comply"73. This intergovernmental interaction fits well within Wright's inclusive authority model. However, the actual way in which Danish IGR develops in practice include elements of the overlapping authority model, due to the bargaining process between central government and associations of local governments through informal "corporatist agreements". From an institutional aspect (formal institutions) we must be aware that this agreements are not legally binding, being in consequence mere recommendations, and actually they were complemented with legal regulations from the central government ${ }^{74}$.

Another way in which central government could exercises control over subnational units is by means of earmarked or task-related central transfers ${ }^{75}$. The role of subnational governments as "agencies of the central government" explain the existence of many central funds as conditioned to specific purposes. The constant tension between local autonomy and central control could be identified in the character of central grants. As MAU explains, "there are two motives on the Central Government agenda: supporting local-level accountability and maintaining influence on the part of the central level" ${ }^{, 76}$. Moreover, Denmark has chosen a decentralized welfare state model which means, on the one hand, that most of the welfare services are delivered by local governments (specifically, the municipal level), but on the other hand, it implies that most of the welfare services have the nature of national rather than local public goods ${ }^{77}$.

There is a great difference in both countries regarding the types of central grants. First, Argentine provinces depend more on central resources, since their own-resources represent 41 per cent in average between 2000 and 2010, whereas Danish subnational levels have 50 per cent in average of own-resources. However, in the last decades, the share of subnational own-resources has decreased since 2007 (from 54 per cent in 2006 to 39 per cent in 2010). Looking at column 4 in Table 1, we can observe that despite Argentine provinces are more dependent on central grants, a major percentage of them are non-earmarked, representing 48 per cent of total subnational resources, against 11 percent of earmarked grants (in average between 2000 and 2010). In the ten-year period, the Danish case shows greater importance of earmarked grants, representing 32 per cent, against 18 per cent of non-earmarked funds. However, it should be noticed that in the evolution of these ten years, non-earmarked grants have gained much more importance: in 2000 they represented 11 per cent and in 2010 they reached up to 29 per cent (almost reaching the same percentage of earmarked grants). This tendency could be translated into more political autonomy for municipalities, especially in the decision making of how and what expend their money. Still, institutional features give predominance to the central government in the decision-making process, which is in charge to design, among other functions, the general guidelines.

\footnotetext{
${ }^{73}$ BLOM-HANSEN (1999) p. 249.

${ }^{74}$ BLOM-HANSEN (1999) p. 251.

${ }^{75}$ See MAU (2010).

${ }^{76}$ MAU (2010) p. 294.

${ }^{77}$ Ibíd.
} 
The large share of non-earmarked grants in Argentina could be explained for the presence of the coparticipation regime, which was classified as a non-earmarked grant. Due to the fact that this regime was a consequence of negotiations between levels of governments (federal and provincial) over constitutional concurrent tax competences, the funds generated within the regime could not be targeted or earmarked to any specific activity or expenditure. On the other hand, there are a large number of specific federal transfers related to specific activities and oriented to finance them (such as education, public health, housing, electricity, etc.), but in overall terms, they represent a lesser share in the total amount transferred to provinces.

Decentralization is a process that could acquires different nuances and features and despite the efforts of many scholars, it is still difficult to measure and to explain their consequences. However, one thing remains clear: processes of decentralization have challenged the classic distinction of states in federal and unitary. Denmark, with its federal practices and the deep decentralization upon municipalities seems to be a federal country in practice; Argentina, a federal country according to its constitutions, has shown more unitary trends, especially regarding fiscal resources. These processes make clear that institutional settings are a process rather than a static outcome, and these processes can flow from one point to another according to the circumstances of the specific country, in a certain time and context.

\section{BIBLIOGRAPHY CITED}

AldASORO, Iñaki and Mike SEIFERLING (2014): "Vertical Fiscal Imbalances and the Accumulation of Government Debt". Available on: https://www.imf.org/external/pubs/ft/wp/2014/wp14209.pdf, date of access: March 7, 2018.

Altavilla, Cristian (2015): "Variables Políticas en la [Re]Distribución de Recursos Fiscales entre distintos niveles de Gobiernos", Revista Perspectivas de Políticas Públicas, Year 3, No 7 (July-Dec.), pp. 13-41.

, (2016): Conflicto y Coordinación política en las Relaciones Intergubernamentales en Argentina. Un análisis neoinstitucional a través del Régimen de Coparticipación Federal de Impuestos (Doctoral Thesis, Córdoba, Universidad Nacional de Córdoba, Argentina).

Blom-HANSEN, Jens (1998): "Macroeconomic Control of Local Governments in Scandinavia: The Formative Years", Scandinavian Political Studies, Vol. 21, N ${ }^{\circ}$ 2, pp. 129-159.

, (1999): "Policy-Making in Central-Local Government Relations: Balancing Local Autonomy, Macroeconomic Control, and Sectoral Policy Goals", Journal of Public Policy, Vol. 19, Issue 03 (Sep.), pp 237-264.

(2010): "The fiscal federalism theory of grants: Some reflections from political science", in KIM, Junghun, LOTZ, Jørgen and MAU, Niels Jørgen (Eds.), General Grants versus Earmarked Grants Theory and Practice (The Copenhagen Workshop 2009, published by Korea Institute of Public Finance and the Danish Ministry of Interior and Health), pp. 107-125. 
Blom-Hansen, Jens and HeEAger, Anne (2011): "Denmark: Between Local Democracy and Implementing Agency of the Welfare State", in LOUGHLIN, John, HENDRIKS Frank and LIDSTRÖM Anders (Eds.), The Oxford Handbook of Local and Regional Democracy in Europe (Oxford, Oxford University Press), pp. 222-240.

DZIOBEK, Claudia et al. (2011): "Measuring Fiscal Decentralization Exploring the IMF's Databases". Available on: https://www.imf.org/external/pubs/ft/wp/2011/wp11126.pdf, date of access: March 7, 2018.

EYRAUD, Luc and LusinYAN, Lusine (2011): "Decentralizing Spending More than Revenue: Does It Hurt Fiscal Performance?". Available on: https://www.imf.org/en/Publications/WP/Issues/2016/12/31/DecentralizingSpending-More-Than-Revenue-Does-it-Hurt-Fiscal-Performance-25266, date of access: March 7, 2018.

FALlETI, Tulia (2005): “A Sequential Theory of Decentralization: Latin American Cases in Comparative Perspective", American Political Science Review, Vol. 99, $\mathrm{N}^{\circ} 3$ (August), pp. 327-346.

Garman, Christopher et al. (2001): "Fiscal Decentralization: A Political Theory with Latin American Cases" World Politics, Vol. 53, Nº 2 (Jan.), pp. 205-236.

GIBSON, Edward and FALLETI, Tulia (2004): "Unity by the Stick: Regional Conflict and the Origins of Argentine Federalism" in GIBSON, Edward (Ed.), Federalism and Democracy in Latin America (Baltimore, John Hopkins University Press), pp. 226-254.

HelmKe, Gretchen and LEVITSKy, Steven (2004): "Informal Institutions and Comparative Politics: A Research Agenda", Perspectives on Politics, Vol. 2, $\mathrm{N}^{\circ}$ 4 (Dec.), pp. 725-740.

HoOGHe, Liesbet and MARKS, Gary (2001): Multi-Level Governance and European Integration (Lanham, Rowman \& Littlefield).

(2003): "Unraveling the Central State, but How? Types of Multilevel Governance", American Political Science Review, Vol. 97, $\quad \mathrm{N}^{\circ} 2, \quad$ pp. 233-243. Available on: http://hooghe.web.unc.edu/files/2016/09/hooghe.marks_.unravelingcentralstate.a psr_.2003.pdf, date of access: March 7, 2018.

JORDANA, Jacint (2002): Relaciones Intergubernamentales y Descentralización en América Latina. Casos de Argentina y Bolivia (Working Paper, INDES I-38UE, Washington, Inter-American Development Bank). Available on: https://issuu.com/idb_publications/docs/working_es_9938, date of access: March 7, 2018. 
MAU, Niels Jørgen (2010): "Grant design in Denmark and factors behind the use of grant earmarking", in KIM, Junghun et al. (Eds.), General Grants versus Earmarked Grants Theory and Practice (The Copenhagen Workshop 2009, published by Korea Institute of Public Finance and the Danish Ministry of Interior and Health), pp. 285-317.

MORTENSEN, Peter Bjerre (2014): "Udviklingen i de offentlige udgifter", in CHRISTIANSEN, Peter (Ed.), Budgetlagning og offentlige udgifter (København, Hans Reitzel), pp. 66-91.

OATES, Wallace (1972): Fiscal Federalism (New York, Harcourt Brace Jovanovich).

PICARD, Louis (1983): “Decentralization, 'Recentralization' \& 'Steering Mechanisms': Paradoxes of Local Government in Denmark”, Polity, Vol. 15, N 4 (Summer), pp. 536-554.

RoDDEN, Jonathan (2004): "Comparative Federalism and Decentralization. On meaning and Measurement", Comparative Politics, Vol. 36, N 4, pp. 481-500.

SCHNEIDER, Aaron (2004): "The Fiscal Sociology of Decentralisation: The impact of Decentralization on Tax Capacity and Pro-Poor Policy", in GUPTA, K. R. (Ed. Coord.), Urban Development Debates in the New Millennium: Studies in Revisited Theories and Redefined Praxes. Volume 1 (New Delhi, Atlantic), pp. 115-182.

SCHWARTZ, G. and LiUKSILA, C. (1997): “Argentina”, in TER-Minassian, Teresa (Ed.), Fiscal Federalism in Theory and Practice (Washington, International Monetary Fund), pp. 387-422.

SWENDEN, Wilfred (2006): Federalism and Regionalism in Western Europe. A Comparative and Thematic Analysis (Basingstoke, Palgrave).

TER-Minassian, Teresa (1997): Fiscal Federalism in Theory and Practice (Washington, International Monetary Fund).

TIEBOut, Charles (1956): "A Pure Theory of Local Expenditures", The Journal of Political Economy, Vol. 64, N 5 (Oct.), pp. 416-424.

TOMmasi, Mariano (2002): Federalism in Argentina and the Reforms of the 1990s, (Working Paper $\quad \mathrm{N}^{\circ}$ 147, May). Available on: https://pdfs.semanticscholar.org/1981/30d620251101ca23b817f6d06c24dd2b72f 5.pdf, date of access: March 7, 2018. 